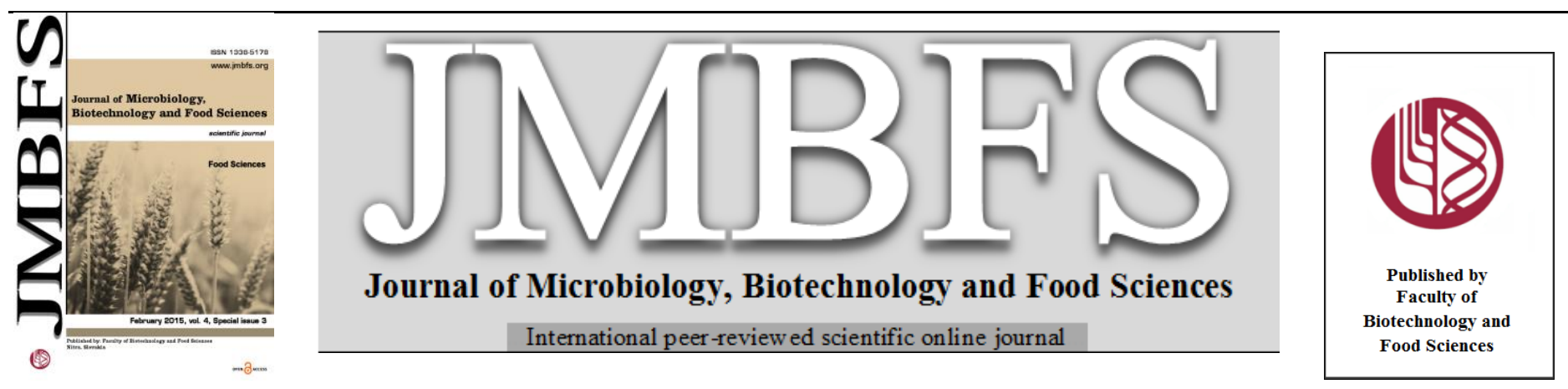

\title{
SELENIUM AND ITS INFLUENCE ON THE CONTENT OF POLYPHENOL COMPOUNDS IN ONION (ALLIUM CEPA L.)
}

\section{Judita Bystrická* ${ }^{1}$, Petra Kavalcová ${ }^{1}$, Janette Musilová $^{l}$, Ján Tomáš ${ }^{1}$, Tomáš Tóth ${ }^{l}$, Matyáš Orsák ${ }^{2}$}

Address(es): doc. Ing. Judita Bystrická, PhD.

${ }^{1}$ Slovak University of Agriculture, Faculty of Biotechnology and Food Sciences, Department of Chemistry, Tr. A. Hlinku 2, 949 76, Slovak Republic, phone number: +421376414353 .

${ }^{2}$ Czech University of Life Sciences, Dept. of Chemistry, Faculty of Agrobiology, Food and Natural Resources, Czech University of Life Sciences Prague, Kamýcká 129, 16521 Prague 6 - Suchdol, Czech Republic.

*Corresponding author:Judita.Bystricka@centrum.sk

doi: 10.15414/jmbfs.2015.4.special3.23-26

\section{ARTICLE INFO}

Received 27. 11.2014

Revised 3. 12.2014

Accepted 4. 12. 2014

Published 2. 2. 2015

Regular article

open $\partial_{\text {ACCESS }}$

\section{INTRODUCTION}

Onion (Allium cepa L.) belongs to the Allium family in common with leek (Allium porrum ) and garlic (Allium sativum), they are higly valued for their flavour and for the nutritional value. Onions are one of the most consumed vegetables with very diverse uses. It can be consumed raw in salad or cooked.

Many studies have suggested (Rio-Del et al., 2010; Geetha et al., 2011; Bernaert et al., 2012) that regular consumption Allium species has a beneficial effects on the human health. The protective effect of vegetables from Allium family against certain diseases such as cancers, cardiovascular disease, has been attributed to the presence of organosulphur compounds as well as polyphenol substances which are located in onion (Han et al., 2013).

Nutrient management for onion production have a significant effect on postharvest behaviour of the produce (Kumar et al., 2007). Different types of soils have different characteristics that influence growth and yield of crops. The type and value of fertilizer and the level of application directly influence plant physiology and the biosynthesis of secundary compounds in plants (Naguib et al., 2012)
(Allium cepa L.) are important source of bioactive compounds including polyphenols and have potential beneficial properties for

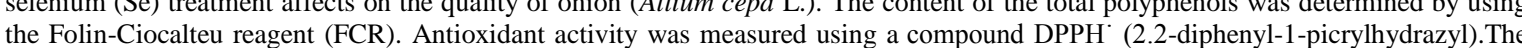
Se treatment increased the content of total polyphenols (TCA) and antioxidant activity (AA). The content of total polyphenols in samples of onion during vegatation period moved in the range from $508.16 \pm 27.59$ to $607.56 \pm 23.15$. In this work was watched also the

Keywords: Selenium, onion, total polyphenols, antioxidant activity
Selenium is a trace element that is essential to good health but is required in small amounts. Allium species have the capability to accumulate high Se levels (Shah et al., 2004). Selenium plays an important role in human and animal nutrition. Its essential component of the number antioxidant enzymes (Kápolna, Fodor, 2006). Selenium is needed to prevent oxidative damage and to support hormone balance in human and animal cells (Fairweather-Tait et al., 2011).

The main purpose of this study was to determine of sulphure on the content of the total polyphenols as well as antioxidant activity of onion.

\section{MATERIAL AND METHODS}

\section{Soil substrate}

In the conditions of growing bowl- shaped pots we were taken of soil from area of Babindol. Babindol is located in the middle of Žitavská upland. Babindol belongs to the relatively warm climatic zone with average annual temperature 9.7 ${ }^{\circ} \mathrm{C}$ and annual rainfall $580 \mathrm{~mm}$. Agrochemical characteristic of soil in that region shown in the Table 1.

Table 1 Agrochemical characteristic of soil substrate in mg.kg-1

\begin{tabular}{|c|c|c|c|c|c|c|c|c|c|}
\hline \multirow{2}{*}{$\begin{array}{l}\text { Agrochemical } \\
\text { characteristic }\end{array}$} & $\begin{array}{c}\mathrm{pH} \\
\left(\mathrm{H}_{2} \mathrm{O}\right)\end{array}$ & $\begin{array}{c}\mathrm{pH} \\
(\mathrm{KCl})\end{array}$ & $\begin{array}{l}\text { Cox } \\
(\%)\end{array}$ & $\begin{array}{l}\text { Hum. } \\
(\%)\end{array}$ & & & & & \\
\hline & 7.75 & 6.60 & 1.19 & 2.05 & & & & & \\
\hline \multirow{2}{*}{ Nutrients } & $\mathrm{N}$ & $\mathrm{K}$ & $\mathrm{Ca}$ & $\mathrm{Mg}$ & $\mathrm{P}$ & & & & \\
\hline & 1225 & 285.80 & 3091.4 & 265.70 & 195.80 & & & & \\
\hline Heavy metals & $\mathrm{Zn}$ & $\mathrm{Cu}$ & $\mathrm{Mn}$ & $\mathrm{Fe}$ & $\mathrm{Cr}$ & $\mathrm{Cd}$ & $\mathrm{Pb}$ & $\mathrm{Co}$ & $\mathrm{Ni}$ \\
\hline Aqua regia & 71.0 & 20.0 & 640.0 & 22785 & 22.60 & 0.72 & 21.20 & 12.40 & 29.20 \\
\hline Limit value & 100.0 & 60.0 & - & - & 70.0 & 0.4 & 70.0 & 15.0 & 40.0 \\
\hline $\begin{array}{c}\mathrm{NH}_{4} \mathrm{NO}_{3}(\mathrm{c}= \\
\left.1 \mathrm{~mol} \cdot \mathrm{dm}^{-3}\right)\end{array}$ & 0.05 & 0.07 & 0.21 & 0.20 & 0.02 & 0.04 & 0.22 & 0.11 & 0.15 \\
\hline $\begin{array}{c}\text { Critical } \\
\text { value }\end{array}$ & 2.0 & 1.0 & - & - & - & 0.1 & 0.1 & - & 1.5 \\
\hline
\end{tabular}

Legend: *Limit value for Aqua raegia - law no. 220/2004 Z.Z.

**Critical value for $\mathrm{NH}_{4} \mathrm{NO}_{3}\left(\mathrm{c}=1\right.$ mol.dm $\left.{ }^{-3}\right)$ - law no. $220 / 2004 \mathrm{Z} . \mathrm{z}$

- not applicable. 
Six kilograms of soil was weighted into plastic bowl-shaped pots with average of $20 \mathrm{~cm}$ and height of $25 \mathrm{~cm}$ with foraminate bottom. Basic nutrients were added in the form of aqueous solution. 8 yellow onion variety of Mundo were planted into each container. Onions of varieties Mundo are flat- cycle and yellow gold colour. The flesh is white, firm, slightly sharper taste. These varieties are well storable with good consumer values The experiment was based on four replications. Basic nutrients were applied in the form of aqueous solution. Selenium was applied in the form $\mathrm{Na}_{2} \mathrm{SeO}_{4}$ Variants of pot experiments are given in Table 2 .

Table 2 Variants of pots experiments

\begin{tabular}{cc}
\hline Variety & Added amount of Se ( $\left.\mathbf{m g} \cdot \mathbf{k g}^{\mathbf{- 1}}\right)$ \\
\hline control & 0 \\
\hline Added Se1 & 0.150 \\
\hline Added Se 2 & 0.225 \\
\hline Added Se 3 & 0.300 \\
\hline
\end{tabular}

\section{Sample preparation}

Samples of fresh onion we collected at the beginning, in the middle and end of vegetation period. Samples of onion were homogenized and we prepared an extract: $25 \mathrm{~g}$ cut onion extracted by $50 \mathrm{ml} 80 \%$ ethanol according sixteen hours These extracts were used by analyze. The experiment was based on four replications

\section{Determination of total polyphenols (TCP)}

Total polyphenols were determined by the method of Lachman et al. (2003) and expressed in mg eq. gallic acid per $\mathrm{kg}$ fresh mater. Gallic acid is usually used as a standard unit for phenolics content determination because a wide spectrum of phenolic compounds. The total polyphenol content was estimated using FolinCiocalteau reagent. The Folin-Ciocalteau phenol reagent was added to a volumetric flask containing an aliquot of extract. The content was mixed and a sodium carbonate solution $(20 \%)$ was added after $3 \mathrm{~min}$. The volume was adjusted to $50 \mathrm{~mL}$ by adding of distilled water. After 2 hours, the samples were centrifuged for $10 \mathrm{~min}$. and the absorbance was measured at $765 \mathrm{~nm}$ of wave length against blank. The concentration of polyphenols was calculated from a standard curve plotted with known concentration of gallic acid.

\section{Determination of antioxidant activity (AOA)}

Antioxidant activity was measured by the Brand-Williams $\boldsymbol{e t}$ al. method (1995) using a compound DPPH (2.2-diphenyl-1-picrylhydrazyl) (Merck). 2.2-diphenyl1-picrylhydrazyl (DPPH) was pipetted into cuvettes $\left(3.9 \mathrm{~cm}^{3}\right)$, then was written the value of absorbance, which corresponded to the initial concentration of DPPH solution in time $\mathrm{A}_{0}$. Then $0.1 \mathrm{~cm}^{3}$ of the followed solution was added and then was immediately started to measure the dependence $A=f(t)$. The solution in the cuvettes were mixed and measured the absorbance of 1,5 and 10 minutes at $515.6 \mathrm{~nm}$ in the spectrophotometer Shimadzu UV/VIS-1240. The percentage of inhibition reflects how the followed compound is able to remove DPPH radical at the given time.

Inhibition $(\%)=\left(\mathrm{A}_{0}-\mathrm{At} / \mathrm{A}_{0}\right) \times 100$

\section{Statistical analysis}

All determinations were done in six repetitions. The data were analysed using the package Statgraphics (multifactorial analysis of variance, LSD-text contrasts, $p<$ $0.05)$

\section{RESULTS AND DISCUSSION}

Onion is an important ingredient in all dishes around the world. It is known for its antimicrobial activity, antioxidant activity, anticarcinogenic and antimutagenic properties (Corzo-Martínez et al., 2007). Onion is one of the rich sources of the polyphenols - quercetin - in human diet. Fertilization plays significant roles in enhancing crop quality. A number of recent studies examined the effect of selenium (Se) on crops including Alliums (Lavu et al., 2012; Põldma et al.
2013; Reilly et al., 2014). Selénium treatment affects plant nutrition and it has a marked effect on the quality of the onion bulbs. Selenium is found in selenoproteins which are important antioxidant enzymes. The antioxidant properties of the selenoproteins prevent cellular damage from free radicals that may contribute to the development of chronic diseases such as cancer, heart disease (Zegenere, Alsin 2008)

In the current experiment the process of the formation of the total polyphenol content after application of different selenium levels was studied in onion (Allium cepa L.) during vegetation period. In the work we watched also the influence of selenium treatment on the antioxidant activity.

Table 3 shows the progress of making the total polyphenolic content in different levels of selenium fertilization in onion during vegetation.

Table 3 Dynamics of changes TPC $\left(\mathrm{mg}^{-\mathrm{kg}^{-1}}\right)$ in onion after selenium application

\begin{tabular}{llll} 
Variety & I. sampling & II. sampling & III. sampling \\
\hline control & $508.16 \pm 27.59 \mathrm{a}$ & $545.0 \pm 19.9 \mathrm{ab}$ & $599.88 \pm 18.54 \mathrm{a}$ \\
\hline Added Se1 & $560.31 \pm 7.59 \mathrm{~b}$ & $566.83 \pm 9.59 \mathrm{bc}$ & $588.03 \pm 12.94 \mathrm{a}$ \\
\hline Added Se 2 & $587.58 \pm 15.27 \mathrm{~b}$ & $584.53 \pm 17.77 \mathrm{c}$ & $607.56 \pm 23.15 \mathrm{a}$ \\
\hline Added Se 3 & $519.09 \pm 17.24 \mathrm{a}$ & $531.59 \pm 17.8 \mathrm{a}$ & $584.42 \pm 16.35 \mathrm{a}$ \\
\hline Legend: *Multiple Range Tests, Method: 95,0 percent LSD
\end{tabular}

Legend: *Multiple Range Tests, Method: 95,0 percent LSD

Our values of total polyphenolic content during vegetation period were in range from $508.16 \pm 27.59$ to $607.56 \pm 23.15$. The highest values of total polyphenols $(607.56 \pm 23.15)$ were recorded in variant II (incorporation of selenium in quantity of $0.225 \mathrm{mg} \mathrm{Se} . \mathrm{kg}^{-1}$ soil) at the end of vegetation period (III. sampling), but statistically significant relationship was not recorded ( $p$-value $>0.05)$. The highest values of total polyphenols were recorded at the end of vegetation period in all variants. The slight decrease in the value of the total polyphenols against control variant (about 1.98\%) was recorded in I. variant (588.03 \pm 12.94$)$ (incorporation of selenium in quantity of $0.15 \mathrm{mg} \mathrm{Se} . \mathrm{kg}^{-1}$ soil) and in variant III (584. $42 \pm 16.35$ ) (incorporation of selenium in quantity of $0.30 \mathrm{mg} \mathrm{Se} . \mathrm{kg}^{-1}$ soil) these decreases compared to the control treatment were not statistically significant. Our results are in good accordance with Motomura et al. (2008), who referred to the positive effect of using selenium fertilizers on the total polyphenol content. Xu et al., (2003) reported that the selenium fertilizers significantly increased the total polyphenols. As is known the content of polyphenols is affected by factors such as cultivar, location, agronomic, environmental conditions and use of fertilizers (Yang et al., 2004; Dangour $\boldsymbol{e t}$ al., 2009).

In this work we watched the effect of selenium on the antioxidant activity. Our values were in interval from $25.90 \pm 0.47$ to $39.72 \pm 2.64$ (Table 4)

Table 4 Dynamics of AOA (\%) in onion after selenium application

\begin{tabular}{llll} 
Variety & I. sampling & II. sampling & III. sampling \\
\hline control & $27.92 \pm 3.36 \mathrm{a}$ & $32.37 \pm 1.68 \mathrm{ab}$ & $32.36 \pm 0.62 \mathrm{a}$ \\
\hline Added Se1 & $29.86 \pm 6.65 \mathrm{ab}$ & $30.20 \pm 6.26 \mathrm{a}$ & $34.87 \pm 2.10 \mathrm{a}$ \\
\hline Added Se 2 & $36.11 \pm 4.70 \mathrm{~b}$ & $36.03 \pm 3.68 \mathrm{~b}$ & $39.72 \pm 2.64 \mathrm{~b}$ \\
\hline Added Se 3 & $25.90 \pm 0.47 \mathrm{a}$ & $27.20 \pm 1.17 \mathrm{a}$ & $38.74 \pm 1.62 \mathrm{~b}$ \\
\hline
\end{tabular}

Legend: *Multiple Range Tests, Method: 95,0 percent LSD

The highest value of antioxidant activity (39.72 \pm 2.64$)$ were recorded in variant II (incorporation of selenium in quantity of $0.225 \mathrm{mg} \mathrm{Se} . \mathrm{kg}^{-1}$ soil) at the end of vegetation period (III. sampling).This increase compared to the control variant was statistically significant ( $p$-value $=5 \cdot 10^{-4}$ ). In our results we have seen a slight decrease in the value of the antioxidant activity (against control variant) in III. variant (incorporation of selenium in quantity of $0.300 \mathrm{mg} \mathrm{Se} . \mathrm{kg}^{-1}$ soil) in first and second sampling, but statistically significant relationship was not recorded $(p$-value $>0.05)$.

Few studies have been reported about the association between selenium content and antioxidant activity plants. Xu et $\boldsymbol{a l}$., (2004) found the positive relationship between the selenium content and the antioxidant activity. Between the content of the selenium in the soil and antioxidant activity (in III. sampling) we have seen a slight positive correlation ( $p$-value $=2.10^{-4}$ ) (Figure 1 ).

At work we have found positive correlation between the content of the total polyphenols and antioxidant activity $\left(p\right.$-value $\left.=6.10^{-3}\right)$. Results are shown in Figure 2. 


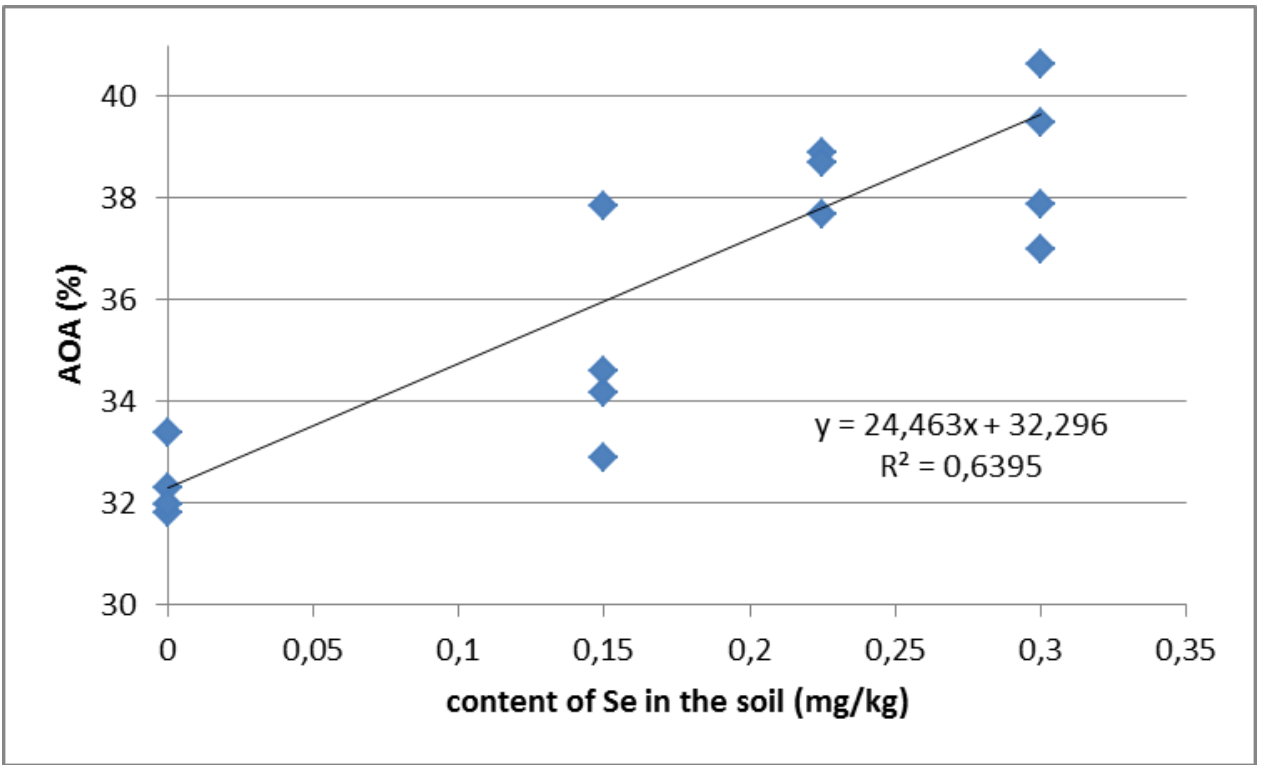

Figure 1 The dependence of the Se content in the soil of the AOA (III. sampling)

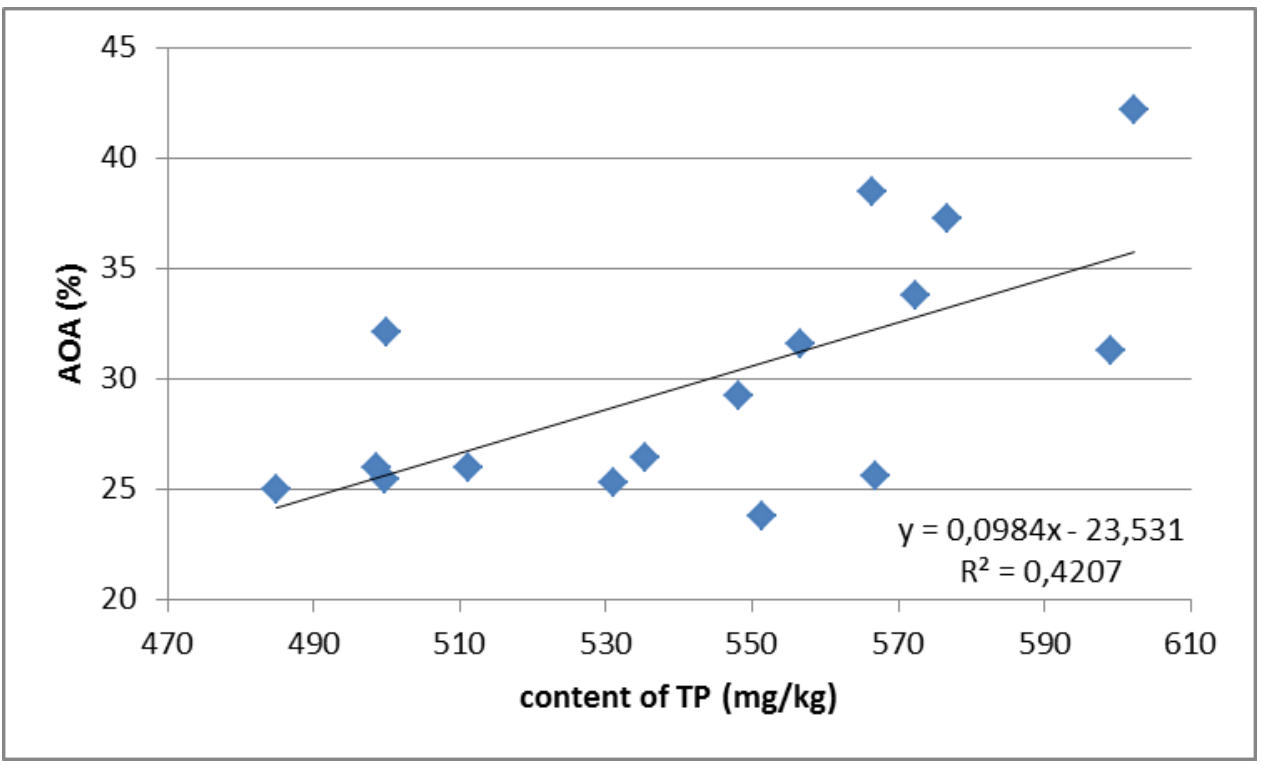

Figure 2: Relationship between TCP and AOA (I. sampling)

\section{CONCLUSION}

Onion (Allium cepa, L.) is one of the most important vegetable crops grown in Slovak Republic. It is a rich source of polyphenols, organic sulphur compounds and saponins. To track the impact of selenium we took advantage of growing experiments. The results suggest that doses of the selenium did not have significant effect on the content of polyphenols. In this work was found positive relationship between the content of the selenium in soil and values antioxidant activity. Application of selenium in quantity of $0.225 \mathrm{mg} \mathrm{Se} \cdot \mathrm{kg}^{-1}$ soil resulted in the highest content of the total polyphenols and the highest value of antioxidant activity. In the next research of the influence of selenium on the bioactive components it should be presented complemented results of the influence of other bulbs of applied doses of selenium and attempts to expand on the small areas cultivation.

Acknowledgments: The work was supported by scientific grant VEGA 1/0290/14, VEGA 1/0456/12

\section{REFERENCES}

BERNAERT, N., DE PAEPE, D., BOUTEN, CH., DE CLERCQ, H., STEWART, D., VAN BOCKSTAELE, E., DE LOOSE, M., VAN DROOGENBROECK, B. 2012. Antioxidant capacity, total phenolic and ascorbate contentas a function of the genetic diversity of leek (Allium ampeloprasum var. porrum). Food Chemistry, 134, 669-677. http://dx.doi.org/10.1016/j.foodchem.2012.02.159.
BRAND-WILLIAMS, W., CUVELIER, M. E., BERSET, C. 1995. Use of a free radical method to evaluate antioxidant activity. Lebensmittel-Wissenschaft and Technologie, 28(1), 25-30. http://dx.doi.org/10.1016/S0023-6438(95)80008-5 CORZO-MARTÍNEZ, M., CORZO, N., VILLAMIEL, M. 2007. Biological properties of onions and garlic. Trends in Food Science \& Technology, 18, 609 625. http://dx.doi.org/10.1016/j.tifs.2007.07.011

DANGOUR, A. D., DODHIA, S. K., HAYTER, A., ALlEN, E., LOCK, K., UAUY, R. 2009. NUTRITIONAL QUALITY OF ORGANIC FOODS: A systematic review. American Journal Clinical Nutrition, 90, 680-685. http://dx.doi.org/10.3945/ajen.2009.28041.

FAIRWEATHER-TAIT, S.J., BAO, Y., BROADLEY, M.R., COLLINGS, R., FORD, D., HESKETH, J.E., HURST, R. 2011. Selenium in human health and disease. Antioxidants \& Redox Signaling, 14, 1337-1383 http://dx.doi.org/10.1089/ars.2010.3275.

GEETHA, M., PONMOZHI, P., SARAVAN, A., KUMAR, M., SUGANYADEVI, P. 2011. Extraction of anthocyanin and analysing its antioxidant properties from different onion (Allium cepa) varieties. Journal Research Pharmaceutical Sciences, 2, 497-506.

HAN, M.H., LEE, W.S., JUNG, J.H., JEONG, J.H., PARK, CH., KIM, G.S. JUNG, J.M., KWON, T.K., KIM, G.Y., RYU, CH. H., SHIN, S.CH., HONG, S.CH., CHOI, Y.H. 2013. Polyphenols isolated from Allium cepa L. induce sapoptosis by suppressing IAP-1 through inhibiting PI3/K/Akt signaling path ways in human leukemic cells. Food and Chemical Toxicology, 62, 382389. http://dx.doi.org/10.1016/j.fct.2013.08.085

KÁPOLNA, E., FODOR, P. 2006. Speciation analysis of selenium enriched green onions (Allium fistulosum) by HPLC-ICP-MS. Microchemical Journal, 84 56-62. http://dx.doi.org/10.1016/j.microc.2006.04.014.

KUMAR, S., IMTIYAZ, M., KUMAR, A. 2007. Effect of differential soil moisture and nutrient regimes on postharvest attributes of onion (Allium cepa L.) 
http://dx.doi.org/10.1016/j.scienta.2006.12.024.

LACHMAN, J., PRONĚK, D., HEJTMÁNKOVÁ, A., PIVEC, V., FAITOVÁ

K. 2003. Total polyphenol and main flavonoid antioxidants in different onion (Allium cepa L.) varieties. Scientia Horticulturae, 30, 142-147.

http://www.agriculturejournals.cz/publicFiles/51932.pdf

LAVU, R.V., Du Laing, G., Van DE WIELE, T., PRATTI, V.L.,

WILLEKENES, K., VANDECASTEELE, B., TACK, F. 2012. Fertilizing soil with selenium fertilizers: impact on concentration, speciation and bioaccessibility of selenium in leek (Allium ampeloprasum ). Journal of Agricultural and Food Chemistry, 60, 10930-10935. http://dx.doi.org/10.1021/jf302931z.

MOTOMURA, Y., REYES-DIAZ, M., GIL, M. 2008. Effect of selenite on the total polyphenol content and antioxidative activity of aqueous and ethanolic extracts in sprouts of four agronomic species. Soil Science and Plant Nutrition, 8, 55-67. http://dx.doi.org/10.4067/s0718-27912008000100005.

NAGUIB, A.E.M., EL-BAZ, F.K., SALAMA, Z.A., HANAA, H.A.E., ALI, H.F., GAAFAR, A.A. 2012. Enhancement of phenolics, flavonoids and glucosinolates of brocolli (Brassica olaracea, var. Italica) as antioxidants in response to organic and bio-organicfertilizers. Journal of the Saudi Society of Agricultural Sciences, 11, 142. http://dx.doi.org/10.1016/j.jssas.2012.03.001.

PÕLDMA, P., MOOR, U., TÕNUTARE, T., HERODES, K., REBANE, R. 2013. Selenium treatment under field conditions affects mineral nutrition, yield and antioxidant properties of bulb onion (Allium cepa L.). Acta Sci. Pol., HortorumCultus, 12, 167-181.

REILLY, K., VALVERDE, J., FINN, L., GAFFNEY, M., RAI, D.K., BRUNTON, N. 2014. A note on the effectiveness of selenium supplementation of Irish- grown Allium crops. Irish Journal of Agricultural and Food Research, 53, 91-99.

RIO-DEL, D., COSTA, D., LEAN, L.G., CROZIER, M.E.J. 2010. Polyphenols and health: What compounds are involved? Nutrition, Metabolism \& Cardiovascular Diseases, $\quad 20, \quad 1-6$. http://dx.doi.org/10.1016/j.numecd.2009.05.015.

SHAH, M., Kannamkruath, S.S., WUILLOID, J.C.A., WUILLOID, R.G., CARUSO, J.A. 2004. Identification and characterization of selenium species in erriched green onion (Allium fistulosum) by HPLC-ICP-MS and ESI-ITMS Journal of Analytical Atomic Spectrometry, 19, 381-386 http://dx.doi.org/10.1039/b312320.

ZEGNERE, L., ALSIN, A. L. 2008. The effect of selenite on growth and storage of onions. Journal of Agronomy, 10, 235-240.

XU, J., YANG, F., CHEN, L., HU, J., HU, Q. 2003. Effect of selenium on increasing the antioxidant activity of tea leaves harvested during the early spring tea producing season. Journal Agricultural and Food Chemistry, 51, 1081-1084. http://dx.doi.org/10.1021/jf020940y.

XU, J. -XU, J. - HU, Q. 2004. Effect of foliar application of selenium on the antioxidant activity of aqueous and ethanolic extracts of selenium-enriched rice. Journal Agricultural and Food Chemistry, 52, 1759-17636.

http://dx.doi.org/10.1021/jf0349836

YANG, J., MEYERS, K.J., VAN DER HEIDE, J., LIU, R.H. 2004. Varieta differences in phenolic content and antioxidant and antiproliferativactivities of onions. Journal of Agricultural and Food Chemistry, 52, 6787-6793. http://dx.doi.org/10.1021/jf0307144 